\title{
Soy protein sensitization in cow's milk allergy patients
}

\author{
Dina Muktiarti, Zakiudin Munasir, Alan R. Tumbelaka
}

\begin{abstract}
Background The management of cow's milk allergy (CMA) is avoidance of cow's milk as strictly as possible. Extensive hydrolyzed protein and amino acid based formulas are recommended dietary products for treatment of CMA. However, they have some disadvantages, such as bitter taste and high cost. Alternative protein sources from vegetable proteins, such as soy, can be used as milk-substitute. Previous studies showed the prevalence of soy allergy in CMA patients in Western countries ranged between 0 to $63 \%$, but the prevalence in Asia was not greater than $20 \%$ and no data about this prevalence in Indonesia.

Objectives To determine the proportion of soy protein sensitization in CMA patients and characteristics of CMA patients who were sensitized to soy protein.

Methods Fifty seven CMA patients who consumed soy protein were taken their blood sample to examine the soy-specific IgE.

Results From 57 CMA patients, we found only $18 \%$ of patients who were sensitized to soy protein. Seven out of ten CMA patients who were sensitized to soy protein were under 12 months old. Atopic dermatitis was the most frequent clinical manifestation $(8 / 10)$ and all of them had family history of atopic diseases. Soy sensitization in IgE-mediated and non-IgE mediated CMA were $6 / 10$ and 4/10, respectively.

Conclusions Proportion of soy sensitization in CMA patients in this study was $18 \%$. Soy protein can be used as an alternative for cow's milk substitute in CMA patients. [Paediatr Indones 2007;47:78-82]
\end{abstract}

Keywords: cow's milk allergy (CMA), soy protein sensitization, soy-specific IgE, food allergy, atopic diseases, extensive hydrolyzed formula.

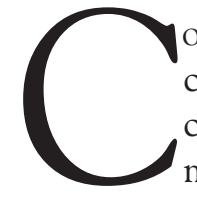
ow's milk allergy (CMA) is one of the most common food allergies in infancy and early childhood. ${ }^{1-3}$ The management of cow's milk allergy is avoidance of cow's milk as strictly as possible. Extensive hydrolyzed protein and amino acid based formulas are the recommended dietary products for CMA's treatment. However, they have some disadvantages, such as bitter taste and high cost. ${ }^{4}$ Alternative protein sources from vegetable proteins, such as soy, could be used as milksubstitute. ${ }^{4,5}$

Previous studies showed that the prevalence of soy allergy in CMA patients ranged between 0 to $63 \% .{ }^{6}$ Therefore, CMA patients were given an extensive hydrolyzed formula to avoid the potential sensitization to soy protein. Most of the studies were conducted in Western countries where consumption of soy was not common. Soy protein has been consumed in Asia for a long time, ${ }^{7}$ but data about prevalence of soy sensitization or allergy in Asia is limited. Recent studies found soy protein sensitization

From the Department of Child Health, Medical School, University of Indonesia, Jakarta, Indonesia.

Reprint requests to: Dina Muktiarti, MD, Department of Child Health, Medical School, University of Indonesia, Cipto Mangunkusumo Hospital, Jl. Salemba 6, Jakarta 10430. Telp. 62-21-3161144. Email: dinamuktiarti@yahoo.com. 
in CMA patients in Western countries ranged between 20 to $59.4 \%$, but after soy protein challenge they found soy allergy ranged between 10-14\%.6,8,9 In Asia, several studies conducted in Korea, Japan, Thailand indicated that soy protein sensitization and allergy were not greater than $20 \%$ (Table 1). ${ }^{10-13}$ There is no reported data about soy protein sensitization or allergy in CMA patients in Indonesia.

The purpose of this study was to identify the proportion of soy protein sensitization in CMA patients and the characteristics of CMA patients with soy protein sensitization.

\section{Methods}

This descriptive, cross-sectional study was conducted in Department of Child Health, Cipto Mangunkusumo Hospital, Jakarta. We enrolled CMA patients who fulfilled the inclusion criteria to join this study. Estimation of the sample size was calculated using a sample size formula for single proportion. Cow's milk

Table 1. Studies on soy protein sensitization and allergy

\begin{tabular}{|c|c|c|c|}
\hline \multirow[t]{2}{*}{ Study } & \multirow[t]{2}{*}{ Population } & \multicolumn{2}{|c|}{ Prevalence (\%) } \\
\hline & & $\begin{array}{c}\text { Soy } \\
\text { sensitization }\end{array}$ & $\begin{array}{l}\text { Soy } \\
\text { allergy }\end{array}$ \\
\hline \multicolumn{4}{|c|}{ Western countries } \\
\hline United States ${ }^{6}$ & CMA & 59.4 & 14 \\
\hline Finland 8 & CMA & 20 & 10 \\
\hline Finland $^{9}$ & CMA & 31 & 0 \\
\hline \multicolumn{4}{|c|}{ Asian countries } \\
\hline \multirow[t]{2}{*}{ Japan $^{13}$} & National survey & ND & 1.4 \\
\hline & Food allergy & ND & 11 \\
\hline Japan ${ }^{11}$ & Food allergy & 20 & ND \\
\hline Thailand ${ }^{12}$ & CMA & ND & 17 \\
\hline Korea $^{10}$ & CMA & 18.3 & ND \\
\hline
\end{tabular}

ND: no data

Table 2. Evaluation of soy-specific lgE classes ${ }^{14}$

\begin{tabular}{cccc}
\hline $\begin{array}{c}\text { Soy- } \\
\text { specific }\end{array}$ & \multicolumn{2}{c}{ Soy-specific IgE (kUA/L) } & Level \\
\cline { 2 - 3 } IgE class & Less than & $\begin{array}{c}\text { Greater than or } \\
\text { equal to }\end{array}$ & \\
\hline 0 & 0.35 & - & Undetectable \\
1 & 0.7 & 0.35 & Low \\
2 & 3.5 & 0.7 & Moderate \\
3 & 17.5 & 3.5 & High \\
4 & 50 & 17.5 & Very high \\
5 & 100 & 50 & Very high \\
6 & - & 100 & Very high \\
\hline
\end{tabular}

allergy patients who had already diagnosed by the previous physician and consumed soy protein were included in this study. The diagnosis of CMA was based on history of allergic manifestations of CMA, elimination and provocation test, and data of $\operatorname{IgE}$ specific or skin prick test of cow's milk. Patients with exclusive breastfeeding or parents refused to join this study were excluded. After informed consent was signed, the parents were interviewed about clinical manifestations of CMA and family history of atopic disease. Blood specimens were taken for determination of soy-specific IgE by Pharmacia CAP system specific IgE fluoroenzymeimmunoassay (FEIA). Soy-specific $\mathrm{IgE}$ greater than or equal to $0.35 \mathrm{kUA} / \mathrm{L}$ were defined as positive and categorized as CMA patients with soy sensitization. Soy-specific IgE classes were divided into 6 classes (Table 2). ${ }^{14}$ All descriptive data were presented in text and tables.

\section{Results}

Fifty-seven CMA patients were enrolled in this study with mean age of 17 months and ranged between two to 60 months; boys outnumbered girls. Atopic dermatitis was the most common CMA's symptoms (60\%), followed by diarrhea (42\%), and chronic cough (33\%). The majority of CMA patients had family history of atopic diseases (91\%). IgE- mediated CMA and non-IgE mediated CMA were $74 \%$ and $26 \%$, respectively (Table 3 ).

Ten out of 57 CMA patients were sensitized to soy protein $(17.5 \%)$. Nine patients had low level of soy-specific $\operatorname{IgE}(0.36-0.69 \mathrm{kUA} / \mathrm{L})$ and one patient had moderate level of soy-specific IgE $(0.74 \mathrm{kUA} /$ L). Mean soy-specific IgE was $0.48 \mathrm{kUA} / \mathrm{L}$. Most of these patients were infants $(7 / 10)$ and after three years of age there were no CMA patients who were sensitized to soy protein. Mean age of CMA patients who were sensitized to soy protein was 13 months. All of CMA patients who were sensitized to soy protein had family history of atopic diseases. Nearly all CMA patients who were sensitized to soy protein had atopic dermatitis $(8 / 10)$, followed by diarrhea (3/10), chronic cough (2/10), and gastroesophageal reflux $(1 / 10)$. Soy sensitization in IgE-mediated and non-IgE mediated CMA were 6/10 and 4/10, respectively (Table 4 ). 
Three of CMA patients who were sensitized to soy protein (patient number 16, 20, and 38) did not have any allergic symptoms when they have already eliminated cow's milk and substituted it with soy

Table 3. Characteristics of CMA patients

\begin{tabular}{|c|c|c|}
\hline Characteristics & $\begin{array}{c}\text { Total } \\
(\mathrm{n}=57)\end{array}$ & $\begin{array}{c}\text { Percentage } \\
(\%)\end{array}$ \\
\hline \multicolumn{3}{|l|}{ Age groups } \\
\hline 0-12 months & 32 & 56 \\
\hline 13-24 months & 13 & 23 \\
\hline 25-36 months & 5 & 9 \\
\hline 37-48 months & 4 & 7 \\
\hline >49 months & 3 & 5 \\
\hline \multicolumn{3}{|l|}{ Gender } \\
\hline Male & 32 & 56 \\
\hline Female & 25 & 44 \\
\hline \multicolumn{3}{|l|}{ Clinical manifestations * } \\
\hline Atopic dermatitis & 34 & 60 \\
\hline Urticaria & 4 & 7 \\
\hline Rhinitis & 5 & 9 \\
\hline Chronic cough & 19 & 33 \\
\hline Asthma & 1 & 2 \\
\hline Diarrhea & 24 & 42 \\
\hline Constipation & 1 & 2 \\
\hline Gastroesophageal reflux & 2 & 4 \\
\hline Anaphylaxis & 0 & 0 \\
\hline \multicolumn{3}{|c|}{ Family history of atopic disease } \\
\hline Positive & 52 & 91 \\
\hline Negative & 5 & 9 \\
\hline \multicolumn{3}{|c|}{ Family member history of atopic disease } \\
\hline Mother & 17 & 30 \\
\hline Father & 18 & 32 \\
\hline Mother and father & 15 & 26 \\
\hline Siblings & 17 & 30 \\
\hline \multicolumn{3}{|l|}{ CMA type $\#$} \\
\hline IgE-mediated & 42 & 74 \\
\hline Non IgE-mediated & 15 & 26 \\
\hline
\end{tabular}

protein. But the others (patient number 5, 6, 13, 18, 29,44 , and 45) still had allergic symptoms. We highly suspected that these seven patients had soy allergy.

\section{Discussion}

Allergic reactions in food allergy can be divided into the sensitization phase, the effector phase and the chronic phase. In the sensitization phase, there were no allergic symptoms but the specific IgE could be already detected by skin prick test or specific IgE examination. ${ }^{15}$ This study only determined soy sensitization by soy-specific IgE examination without elimination and challenge test with soy protein to prove that the symptoms were still existed because of soy allergy. For that reason, this study could not describe proportion of soy allergy in CMA patients.

Cow's milk allergy is one of the most common food allergies in infancy and early childhood because generally cow's milk was the first foreign protein introduced to infants. ${ }^{1,2}$ Management of CMA is avoidance of cow's milk protein. It is recommended that dietary products for treatment of CMA should be tolerated by at least $90 \%$ patients with CMA. These criteria fulfilled by extensive hydrolyzed protein and amino acid based products. ${ }^{4}$ American Academy of Pediatrics (AAP) recommended that soy formula could be given in the IgE-mediated CMA patients above six months old. ${ }^{16}$

Soy formula was described as cow's milk substitute for CMA since 1929 with some advantages, i.e., free of cow-milk protein, lower immunogenicity and allergenicity than cow-milk formulas, nutritional

Table 4. Characteristics of CMA patients with soy protein sensitization

\begin{tabular}{ccccccc}
\hline No & $\begin{array}{c}\text { Age } \\
\text { (months) }\end{array}$ & $\begin{array}{c}\text { Family history } \\
\text { of atopic } \\
\text { disease }\end{array}$ & $\begin{array}{c}\text { Clinical } \\
\text { manifestation(s) } \\
\text { of CMA }\end{array}$ & CMA type & $\begin{array}{c}\text { Soy- } \\
\text { specific } \\
\text { IgE }\end{array}$ & $\begin{array}{c}\text { IgE } \\
\text { Class }\end{array}$ \\
\hline 5 & 7 & + & AD, D & Non IgE-mediated & 0.69 & 1 \\
6 & 11 & + & AD & IgE-mediated & 0.74 & 2 \\
13 & 2 & + & AD & Non IgE-mediated & 0.41 & 1 \\
16 & 36 & + & AD & IgE-mediated & 0.46 & 1 \\
18 & 19 & + & D, CC & IgE-mediated & 0.46 & 1 \\
20 & 8 & + & AD, CC & IgE-mediated & 0.46 & 1 \\
29 & 28 & + & D, GER & IgE-mediated & 0.48 & 1 \\
38 & 5 & + & AD & Non IgE-mediated & 0.36 & 1 \\
44 & 7 & + & AD & Non IgE-mediated & 0.36 & 1 \\
45 & 8 & + & AD & IgE-mediated & 0.36 & 1 \\
\hline
\end{tabular}

AD: atopic dermatitis; D: diarrhea; CC: chronic cough; GER: gastroesophageal reflux 
Dina Muktiarti et al: Soy protein sensitization in cow's milk allergy patients

adequacy similar to cow-milk formulas, better palatability and less expensive than extensive hydrolyzed formulas. ${ }^{5}$ Cross reaction between soy (11 S globulin) and cow's milk allergen (casein) was found in few cases. ${ }^{17}$ Most Asian children are exposed to soybased food, such as formula, tofu or soy sauce, since a very young age. Many Asian mothers choose tofu for weaning because it is widely available at low cost. The soft consistency is also an important factor. Asian infants accept tofu because it is highly palatable. ${ }^{7}$

Unfortunately, previous studies showed that the prevalence of soy allergy in CMA patients was relatively high, and consequently, CMA patients were given an extensive hydrolyzed formula as milk substitute to avoid the potential sensitization to soy protein. ${ }^{6}$ Proportion of soy sensitization in CMA patients in this study was $17.5 \%$, which was similar to that of other studies in Asia ${ }^{10-13}$ and lower than that of other studies in Western countries. ${ }^{6,8,9}$ Mean soy-specific $\operatorname{IgE}$ was $0.48 \mathrm{kUA} / \mathrm{L}$ which is categorized as low level of allergen. This result was lower than that of other studies. Other studies found the mean soy-specific IgE was moderate and very high levels of allergen. ${ }^{6,10}$

Most of CMA patients who were sensitized to soy were under 12 months old and after three years of age there were no CMA patients who were sensitized to soy. It indicates that immaturity of the immune system and gastrointestinal tract predisposes young infants to food sensitization and allergy because gradual maturation of mucosal immune response and intestinal barrier occur in the first 2 years of life. ${ }^{18}$

Most of them also suffered from atopic dermatitis which is in accordance with other studies. ${ }^{10,19,20}$ Soy sensitization in IgE-mediated and non-IgE mediated CMA were similar. Klemola et $\mathrm{al}^{8}$ also reported that adverse reactions to soy were similar in IgE-mediated and non IgE-mediated CMA.

Seven out of ten CMA patients who were sensitized to soy protein had allergic symptoms. We highly suspected that these patients had soy allergy as well, although we had not performed elimination and provocation test yet. However, the test still needs to be done to make a definitive diagnosis. Previous studies showed that only a minority of patients with positive soy-specific IgE had any allergic symptoms or a suspicion of soy allergy. ${ }^{6,8,9,20-23}$ In some cases, IgE to soy could also reflect a cross-reaction with other legumes without demonstrating specific clinical symptoms to soy. ${ }^{11}$

In conclusion, proportion of soy sensitization in CMA patients in this study is $17.5 \%$, which is similar to other studies in Asia, and low level of soy-specific $\operatorname{lgE}(0.48 \mathrm{kUA} / \mathrm{L})$. For clinical practice, soy protein could be used as an alternative for cow's milk-substitute in CMA patients with caution of soy allergy. Further studies consist of larger sample size with elimination and challenge test are needed to determine proportion of soy allergy in CMA patients in Indonesia.

\section{Acknowledgement}

We thank Ethical Nutrition Division of PT. Abbott Indonesia for their support in this research.

\section{References}

1. Sampson HA. Adverse reactions to foods. In: Middleton E, Reed CE, Ellis EF, Adkinson NF, Yunginger JW, Busse WW, editors. Allergy principles and pratice, volume II. $4^{\text {th }}$ edition. St.Louis: Mosby; 1993. p. 1661-86.

2. Siregar SP, Munasir Z. Pentingnya pencegahan dini dan tata laksana alergi susu sapi. Sari Pediatri 2006;7:237-43.

3. Host A. Frequency of cow's milk allergy in childhood. Ann Allergy Asthma Immunol 2002;89:33-7.

4. Host A, Koletzko B, Dreborg S, Muraro A, Wahn U, Aggett P, et al. Dietary products used in infants for treatment and prevention of food allergy. Joint statement of the European Society for Paediatric Allergology and Clinical Immunology (ESPACI) Committee on Hypoallergenic Formulas and the European Society for Paediatric Gastroenterology, Hepatology and Nutrition (ESPGHAN) Committee on Nutrition. Arch Dis Child 1999;81:80-4.

5. Businco L, Bruno G, Giampietro PG. Soy protein for the prevention and treatment of children with cow-milk allergy. Am J Clin Nutr 1998;68:1447S-52S.

6. Zeiger RS, Sampson HA, Bock SA, Burks AW, Harden K, Noone S, et al. Soy allergy in infants and children with IgEassociated cow's milk allergy. J Pediatr 1999;134:614-22.

7. Quak SH, Tan SP. Use of soy-protein formula and soyfood for feeding infants and children in Asia. Am J Clin Nutr 1998;68:1444S-6S.

8. Klemola T, Vanto T, Juntunen-Backman K, Kalimo K, Korpela R, Varjonen E. Allergy to soy formula and to exten- 
Dina Muktiarti et al: Soy protein sensitization in cow's milk allergy patients

sively hydrolyzed whey formula in infants with cow's milk allergy: a prospective randomized study with a follow-up to the age of 2 years. J Pediatr 2002;140:219-24.

9. Klemola T, Kalimo K, Poussa T, Juntunen-Backman K, Korpela R, Valovirta E, Vanto T. Feeding a soy formula to children with cow's milk allergy: the development of immunoglobulin E-mediated allergy to soy and peanuts. Pediatr Allergy Immunol 2005;16:641-6.

10. Ahn KM, Han YS, Nam SY, Park HY, Shin MY, Lee SI. Prevalence of soy protein hypersensitivity in cow's milk proteinsensitive children in Korea. J Korean Med Sci 2003;18:4737 .

11. Allergen data collection. Soybean (Glycine max). Internet Symposium on Food Allergens 1999;1:51-79.

12. Harikul S, Haruehasavasin Y, Varavithya W, Chaicumpa W. Cow milk protein allergy during the first year of life: a 12 year experience at the Children's Hospital, Bangkok. Asian Pac J Allergy Immunol 1995;13:107-11.

13. Ebisawa M, Ikematsu K, Imai T, Tachimoto H. Food allergy in Japan. Allergy Clin Immunol Int 2003;15:214-7.

14. Pharmacia Diagnostics. Pharmacia CAP system spesific IgE FEIA. Swedia: Pharmacia Diagnostics AB; 2004. p. 1-8.

15. Bischoff SC, Sellge G. Immune mechanisms in food-induced disease. In: Metcalfe DD, Sampson HA, Simon RA, editors. Food allergy: adverse reactions to foods and food additives. $3^{\text {rd }}$ edition. Massachusetts: Blackwell Publishing; 2003. p.14-37.
16. Committee on Nutrition American Academy of Pediatrics. Soy protein-based formulas: recommendations for use in infant feeding. Pediatrics 1998;101:148-53.

17. Rozenfeld P, Docena GH, Anon MC, Fossati CA. Detection and identification of a soy protein component that crossreacts with caseins from cow's milk. Clin Exp Immunol 2002; 130:49-58.

18. Nowak-Wegrzyn A, Sampson HA. Adverse reaction to food. Med Clin N Am 2006;90:97-127.

19. Naspitz CK, Sole D, Jacob CA, Sarinho E, Soares FJP, Dantas $\mathrm{V}$. Sensitization to inhalant and food allergens in Brazilian atopic children by in vitro total and specific IgE assay. Allergy Project-PROAL. J Pediatr 2004;80:203-10.

20. Bruno G, Giampietro PG, Del Guercio MJ, Gallia P, Giovannini L, Lovati C. Soy allergy is not common in atopic children: a multicenter study. Pediatr Allergy Immunol 1997;8:190-3.

21. Magnolfi CF Zani G, Lacava L, Patria MF, Bardare M. Soy allergy in atopic children. Ann Allergy Asthma Immunol 1996;77:197-201.

22. Giampietro PG, Ragno V, Daniele S, Cantani A, Ferrara M, Businco L. Soy hypersensitivity in children with food allergy. Ann Allergy 1992;69:143-6.

23. Ellman LK, Chatchateel P, Sicherer SH, Sampson HA. Food hypersensitivity in two groups of children and young adults with atopic dermatitis evaluated a decade apart. Pediatr Allergy Immunol 2002:13;295-8. 